\title{
PENGEMBANGAN LEMBAR KERJA SISWA (LKS) BERBASIS PENDEKATAN REALISTIC MATHEMATIC EDUCATION (RME) UNTUK MEMFASILITASI KEMAMPUAN REPRESENTASI MATEMATIS SISWA SMP
}

\author{
RANTI MUSTIKA SARI \\ ZUBAIDAH AMIR M.Z. \\ RISNAWATI \\ Ranti.taufik.ilhan@gmail.com \\ Program Studi Pendidikan Matematika, FTK \\ Univerisitas Islam Negeri Sultan Syarif Kasim Riau. Pekanbaru
}

\begin{abstract}
Abstrak. Penelitian ini bertujuan untuk mengembangkan dan menghasilkan LKS matematika berbasis pendekatan Realistic Mathematic Educationyang valid dan praktis serta dapat memfasilitasi kemampuan representasi matematis siswa pada materi Sistem Persamaan Linier Dua Variabel. Penelitian ini merupakan penelitian pengembangan dengan menggunakan model 4-D (Define, Desaign, Develop, dan Disseminate). Penelitian ini dilakukan di SMP Negeri 2 Pasir Penyu. Subjek penelitian adalah 29 siswa kelas VIII 1 dan objek penelitian adalah LKS matematika berbasis pendekatan Realistic Mathematic Education. Instrumen pengumpulan data berupa angket uji validitas, angket uji praktikalitas dan tes kemampuan representasi matematis. Penelitian ini menyimpulkan bahwa hasil uji validitas LKS berbasis Realistic Mathematic Education pada materi Sistem Persamaan Linier Dua Variabel di SMP Negeri 2 Pasir Penyu dengan kategori valid dengan persentase $78,21 \%$. Maka hal ini membuktikan bahwa LKS yang dikembangkan dinyatakan valid oleh para validator karena telah memenuhi seluruh komponen dan telah mengalami revisi produk. Hasil uji praktikalitas oleh siswa dinyatakan sangat praktis dengan persentase 94,16\%. LKS matematika berbasis pendekatan Realistic Mathematic Educationtelah berhasil memfasilitasi kemampuan representasi matematis siswa degan persentase tingkat penguasaan siswa 82,5\%. Hasil tersebut menunjukan bahwa LKS matematika berbasis pendekatan Realistic Mathematic Educationini valid, sangat praktis, dan dapat memfasilitasi kemampuan representasi matematis siswa.
\end{abstract}

\section{Kata Kunci: LKS, Realistic Mathematic Education, Kemampuan Representasi}

\begin{abstract}
This research aimed at developing, producing a valid and practical students' workbook Realistic Mathematic Education Approach Based and facilitating student mathematic representing ability on Systems of Linear Equations in Two Variables material.The method of this research was a Research and Development (R\&D) through the development of 4-D (Define, Design, Develop, and Disseminate) Model.This research was administered at State Junior High School 2 Pasir Penyu.The subjects of this research were 29 students of class VIII 1, and the object was student mathematic workbook Realistic Mathematic Education Approach Based.The questionnaire tests of validity, practicality, and mathematic representing test. were the instruments of collecting data.It could be concluded that validity test result on student workbook Realistic Mathematic Education Approach Based on Systems of Linear Equations in Two Variables material at State Junior High School 2 Pasir Penyu was on valid category (78.21\%).It proved that the developed student workbook was avowed by validators because it accomplished all components, and it was a revised product.Practicality test result by students was avowed very practical (94.16\%).Student mathematic workbook Realistic Mathematic Education
\end{abstract}


Approach Based successfully facilitated student mathematic representing ability with the percentage of mastery level $82.5 \%$. The result showed that Student mathematic workbook Realistic Mathematic Education Approach Based was valid, practical, and student mathematic representing ability.

Keywords: Student Workbook, Realistic Mathematic Education, Representing Ability

\section{PENDAHULUAN}

Representasi adalah pusat dari pembelajaran matematika. Siswa dapat mengembangkan dan memperdalam pemahaman mereka akan konsep dan hubungan antar konsep matematika yang telah mereka miliki melalui membuat, membandingkan, dan menggunakan. Representasi merupakan proses pengembangan mental yang sudah dimiliki seseorang, yang terungkap dan divisualisasikan dalammempersentasikan masalah seperti mengkonstruksi dan menggunakan representasi matematis di dalam kata-kata, grafik, tabel, dan persamaan-persamaan, penyelesaian dan manipulasi simbol.

Pengajaran matematika harus melibatkan guru dan siswa secara aktif artinya kegiatan belajar mengajar tidak hanya menyampaikan berbagai informasi seperti aturan, definisi, dan prosedur untuk dihafal siswa tetapi guru juga harus melibatkan siswa dalam proses tersebut. Dengan begitu siswa mampu membangun pemahamnnya sendiri. Setiap manusia mempunyai karakter yang berbeda, begitu pula dengan siswa mereka mempunyai cara yang berbeda dalam proses pemecahan masalah. Bruner mengatakan bahwa proses pemecahan masalah yang sukses bergantung kepada keterampilanmempersentasikan masalah seperti mengkonstruksi dan menggunakan representasi matematis di dalam kata-kata, grafik, tabel, dan persamaan-persamaan, penyelesaian dan manipulasi simbol.

Indikator kemampuan representasi yang perlu diukur dalam penelitian yaitu: 1) Symbolic representation. Siswa mampu membuat dan menyatakan model matematika daripermasalahan yang diberikan,Siswa mampu menyelesaikan dari model matematika yang telah dibuat. 2) Pictorial representation. Siswa mampu menyatakan ide matematika kedalam bentuk grafik, gambar ataupun diagram. 3) Verbal representation of the world problem. Siswa mampu menyatakan atau menafsirkan permasalahan dengan bahasa sendiri secara tertulis.

Matematika merupakan suatu aktivitas manusia, ini merupakan pernyataan freudenthal yang melandasi pengembangan pendekatan RME. Kata relistik sering disalah artikan real world yaitu dunia nyata, banyak pihak yang menganggap bahwa RME adalah pendekatan pembelajaran matematika yang harus selalu menggunkan masalah sehari-hari. Penggunaan kata realistic diambil dari bahasa Belanda dari kata zich realiseren yang berarti "untuk dibayangkan", kata realistic lebih berfokus pada penggunaan situasi yang bisa dibayangkan (imagineable) oleh siswa atau lebih menekankan bahwa siswa mampu membayangkan situasi yang diberikan, dan titik tekannya bukan pada keaslian masalah, namun demikian bukan berarti bahwa keterhubungan dengan situasi kehidupan nyata tidak penting akan tetapi yang menjadi penekanan bahwa konteks tidak harus dibatsi pada dunia nyata.

Realistic Mathematics Education adalah suatu pendekatan pembelajaran yang lebih menekankan agar siswa lebih aktif dalam kegiatan pembelajaran sehingga siswa mampu menemukan sendiri konsepnya, posisi pendidik dalam pembelajaran matematika adalah untuk bernegosiasi dengan siswa, bukan memberikan jawaban akhir yang telah jadi. Tidak hanya itu, pendidik seharusnya diharapkan dapat bertindak sebagai mediator dan fasilitator yang membuat situasi yang kondusif untuk terjadinya konstruksi pengetahuan pada diri siswa. 
Menurut Gravemeijer sebagai suatu pendekatan pembelajaran matematika, pendidikan matematika realistic memiliki lima karakteristik yaitu: a) Menggunakan masalah kontekstual (the use of context), proses pembelajaran diawali dengan masalah kontekstual yang dilihat.b) Menggunakan model atau instrument vertical (bridging by vertical instrument), penggunaan instrument-instrumen vertical berupa model, skema, diagram ataupun simbol sebagai jembatan antara prosedur informal dengan bentuk formal. c) Kontribusi siswa (student contribution), siswa aktif mengkonstruksi sendiri bahan matematika strategi pemecahan masalah dengan bimbingan guru. d) Kegiatan interaktif (interactivity), siswa diberi kesempatan menyampaikan ide-ide, melakukan negosiasi secara eksplisit, berkolaborasi dan evaluasi antar siswa, perangkat belajar, dan interaksi siswa dengan guru secara konstruktif. e) Keterkaitan (interwining), topik-topik yang berbeda dapat diintegrasikan sehingga dapat memunculkan pemahaman tentang suatu konsep secara serentak.

Menurut Setyawati,untuk melaksanakan pengembangan perangkat pembelajaran diperlukan model pengembangan perangkat yang sesuaidengan sistem pendidikan.

Beberapa model penelitian pengembangan perangkat yang dapat digunakan di dunia pendidikan diantaranya yaitu model Plomp, Kemp dan Thiagarajan.

\section{METODE}

Dalam penelitian ini dilakukan pengembangan perangkat pembelajaran, sehingga penelitian ini dapat digolongkan dalam jenis penelitian pengembangan. Adapun model pengembanganyang diadaptasi adalah model 4-D. Produk yang dihasilkan berupa LKS dengan pendekatan Realistic Mathematic Educationpada materi sistem persamaan linear dua variabel yang valid, praktis, dan dapat mempasiltasi kemampuan representasi matematis.

Thiagarajan mengembangkan model perangkat pembelajaran yang dikenal dengan Four-D Model atau Model 4-D. Model ini terdiri atas empat tahap, yaitu: pendefinisian (define), perencanaan (design), pengembangan (develop), dan penyebaran (dessiminate). Namun dalam penelitian ini dilakukan hanya sampai pada tahap ketiga, yaitu tahap pendefinisian (define), tahap perencanaan (design), tahap pengembangan (develop). Hal ini dikarenakan pelaksanaan tahap penyebaran memerlukan proses dan waktu yang lama.

\section{Define (Pendefinisian)}

Tujuan tahap ini adalah menetapkan dan mendefinisikan syarat-syarat pembelajaran. Dalam menentukan dan menetapkan syarat-syarat pembelajaran diawali dengan analisis tujuan dari batasan materi yang dikembangkan bahan ajarnya berupa (LKS). Adapun langkah-langkahnya sebagai berikut:

a. Analisis Kurikulum

Pada tahap awal, peneliti perlu mengkaji kurikulum yang berlaku pada saat itu. Dalam kurikulum terdapat kurikulum yang ingin dicapai, analisis kurikulum berguna untuk menetapkan pada kompetensi yang mana bahan ajar tersebut akan dikembangkan. Hal ini dilakukan karena ada kemungkinan tidak semua kompetensi yang ada dalam kurikulum dapat disediakan bahan ajarnya.

b. Analisis KarakteristikSiswa

Seperti layaknya seorang guru akan mengajar, guru harus mengenali karakteristik siswa yang akan menggunakan bahan ajar. Hal ini penting karena semua proses pembelajaran harus disesuaikan dengan karakteristik siswa. Hal-hal yang perlu dipertimbangkan untuk mengetahui karakteristik siswa antara lain: kemampuan akademik individu, karakteristik fisik, kemampuan kerja kelompok, motivasi belajar, latarbelakang ekonomi dan sosial, pengalaman belajar 
sebelumnya dsb. Dalam kaitannya dalam pengembangan bahan ajar, karakteristik siswa perlu diketahui untuk menyusun bahan ajar yang sesuai dengan kemampuan akademiknya misalnya: apabila tingkat akademis siswa masih rendah maka penulisan bahan ajar harus menggunakan bahasa dan kata-kata sederhana yang mudah dipahami. Apabila minat baca siswa masih rendah maka bahan ajar perlu ditambah dengan ilustrasi gambar yang menarik supaya siswa termotivasi untuk membacanya.

c. Analisis Materi

Analisis materi dilakukan dengan cara mengidentifikasi materi utama yang perlu diajarkan, mengumpulkan dan memilih materi yang relevan dan menyusunnya secara sistematis.

d. Merumuskan Tujuan

Sebelum menulis bahan ajar, tujuan pembelajaran dan kompetensi yang hendak diajarkan perlu dirumuskan terlebih dahulu. Hal ini berguna untuk membatasi peneliti supaya tidak menyimpang dari tujuan semula pada saat mereka sedang menulis bahan ajar.

\section{Design (Perancangan)}

Pada tahap design yang dilakukan adalah merancang bahan ajar berupa LKS berbasis RME secara untuk materi matematiaka sistem persamaan linear dua variabel (SPLDV) tujuan dari tahap ini adalah untuk menyiapkan materi pelajaran. Hal ini dimulai setelah tujuan-tujuan pembelajaran dibuat. Ada dua langkah dalam tahap ini yaitu:

a. Pemilihan Format

Format disesuaikan dengan format yang diperlukan dalam LKS. Sebelumnya dilakukan pengkajian format-format LKS yang beredar dipasaran. Kemudian dikembangkan berdasarkan kriteria LKS yang akan dibuat.

b. Perancangan Awal

Kegiatan utama dengan perancangan awal adalah penulisan, penelaahan dan pengeditan LKS yang dibuat. Desain awal seacara umum berupa:

1) Kegiatan pendahuluan berisi: pada sajian pendahuluan perlu disajikan pengantar mengapa materi itu penting, dan bagaimana kaitan dengan materimateri lainnya. Hal yang penting juga adalah sajian tujuan pembuatan perlu dilampirkan untuk memotivasi siswa untuk mempelajari materi lebih lanjut.

2) Kegiatan isi berisi: materi matematika berbasis RME, kegiatan ini berisi uraian materi yang lengkap hal ini dilengkapi dengan uraian contoh, simulasi dan demonstrasi atau peragaan.

3) Kegiatan penutup berisi: kegiatan penutup diisi dengan kesimpulan atau rangkuman dan juga kegiatan lanjut dari LKS tersebut.

\section{Develop (Pengembangan)}

Tujuan dari tahap ini adalah untuk menghasilkan bahan ajar yang sudah di revisi berdasarkan masukan dari para pakar. Tahap ini menghasilkan bahan ajar dalam bentuk LKS pembelajaran yang telah divalidasi oleh dosen pembimbing dan pakar. Tahap ini meliputi:

a. Tahap Validitas LKS

Tahap validitas merupakan tahap penilaian oleh validator. Dalam tahap ini langsung diikuti dengan tahap revisi yang berguna untuk memperoleh masukan dalam perbaikan LKS. Tujuan dari validasi ini adalah untuk memeriksa kebenaran materi, tatabahasa dan keefektifan LKS dalam mencapai tujuan pembelajaran yang ditargetkan oleh LKS tersebut. Validitas LKS dilakukan oleh dosen ahli media dan 
materi jurusan pendidikan matematika Universitas Islam Negeri Sultan Syarif Kasim Riau sesuai bidang kajiannya dan Guru Matematika

b. Tahap Praktilitas LKS

Setelah melalui tahap Validasi, LKS direvisi dan selanjutnya uji coba terbatas sekolah yang dipakai dalam pengujian tahap ini adalah SMP N 2 Pasir PenyuTahap Praktilitas dilakukan untuk mengetahui tingkat kepraktisan LKS yang digunakan oleh siswa dan guru. Kegiatan ini dilakukan untuk mengetahui sejauh mana manfaat penggunaan dan efisiensi waktu oleh siswa dan guru.

\section{HASIL PENELITIAN DAN PEMBAHASAN}

Penelitian pengembangan ini menghasilkan suatu produk berupa Lembar Kerja Siswa (LKS) dengan materi pokok Sistem Persamaan Linear Dua Variabel (SPLDV) untuk siswa kelas VIII SMP Negeri 2 Pasir Penyu, Dalam pengembangan produk ini menggunakan model pengem

\section{Define}

Tujuan tahap ini adalah menetapkan dan mendefinisikan syarat-syarat pembelajaran. Dalam menentukan dan menetapkan syarat-syarat pembelajaran diawali dengan analisis tujuan dari batasan materi yang dikembangkan bahan ajarnya berupa (LKS). Adapun langkah-langkahnya sebagai berikut:

a. Analisis Kurikulum

Pada tahap awal, peneliti perlu mengkaji kurikulum yang berlaku pada saat itu. Dalam kurikulum terdapat kurikulum yang ingin dicapai, analisis kurikulum berguna untuk menetapkan pada kompetensi yang mana bahan ajar tersebut akan dikembangkan.

b. Analisis Karakteristik Siswa

Seperti layaknya seorang guru akan mengajar, guru harus mengenali karakteristik siswa yang akan menggunakan bahan ajar. Hal ini penting karena semua proses pembelajaran harus disesuaikan dengan karakteristik siswa. Siswa SMP yang menggunakan LKS ini sudah mencapai usia 11 tahun, pada usia ini siswa sudah dapat berhubungan dengan peristiwa-peristiwa hipotesis atau abstrak, tidak hanya berkaitan dengan peristiwa konkret

Tabel 1. Hasil Wawancara Dengan Guru Matematika

\begin{tabular}{|c|c|}
\hline PERTANYAAN & JAWABAN \\
\hline $\begin{array}{l}\text { 1. Bagaimanakah LKS yang biasanya } \\
\text { digunakan oleh siswa? }\end{array}$ & $\begin{array}{l}\text { 1. LKS yang digunakan biasanya oleh } \\
\text { siswa dalam pembelajaran } \\
\text { matematika adalah LKS yang berisi } \\
\text { ringkasan materi, contoh dan latihan } \\
\text { soal-soal }\end{array}$ \\
\hline $\begin{array}{l}\text { 2. Apakah LKS yang digunakan dapat } \\
\text { memfasilitasi kemampuan representasi } \\
\text { matematis siswa? }\end{array}$ & $\begin{array}{l}\text { 2. Berdasarkan soal-soal yang sudah } \\
\text { dikerjakan oleh siswa, setelah } \\
\text { menerima materi dan diberikan } \\
\text { contoh soalnya siswa mampu } \\
\text { menyelesaikan permasalahan yang } \\
\text { disajikan. Namun hanya sebagian } \\
\text { kecil siswa mampu menyelesaikan } \\
\text { permasalahan yang disajikan. }\end{array}$ \\
\hline $\begin{array}{l}\text { 3. Bagaimanakah tingkat kemampuan } \\
\text { representasi matematis siswa? Apakah } \\
\text { siswa mampu menterjemahkan dan }\end{array}$ & $\begin{array}{l}\text { 3. Berdasarkan hasil siswa mengerjakan } \\
\text { soal-soal yang berbentuk cerita dan } \\
\text { bersifat kontekstual, sebagian besar }\end{array}$ \\
\hline
\end{tabular}




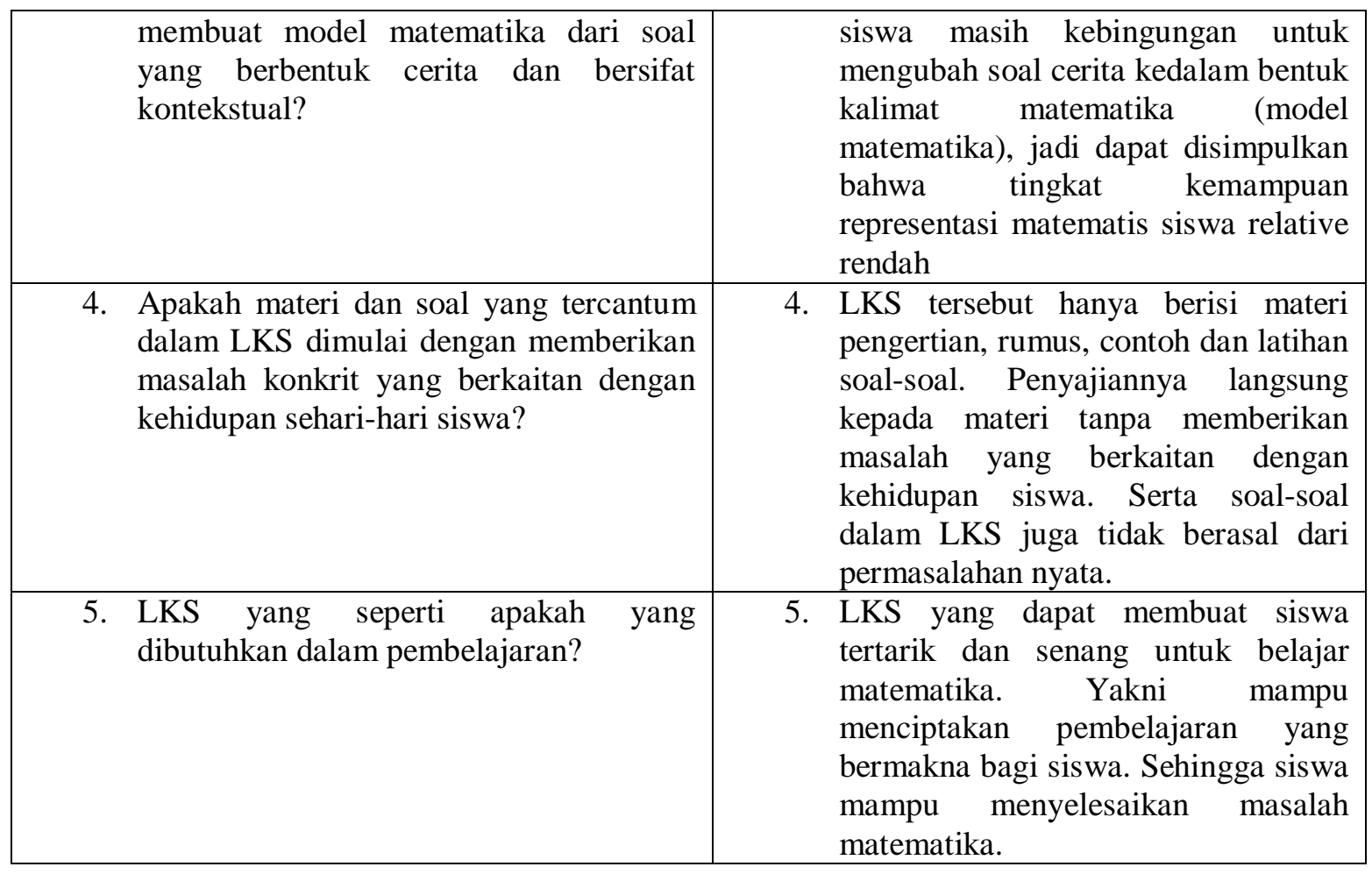

\section{c. Analisis Materi}

Analisis materi dilakukan dengan cara mengidentifikasi materi utama yang perlu diajarkan, mengumpulkan dan memilih materi yang relevan dan menyusunnya secara sistematis. Dalam hal ini penulis telah melakukan analisis materi bahwa materi yang akan dijadikan kajian penelitian adalah Sistem Persamaan Linier Dua Variabel (SPLDV)

d. Merumuskan Tujuan

Sebelum menulis bahan ajar, tujuan pembelajaran dan kompetensi yang hendak diajarkan perlu dirumuskan terlebih dahulu. Hal ini berguna untuk membatasi peneliti supaya tidak menyimpang dari tujuan semula pada saat menulis bahan ajar.

\section{Desaign}

Desaign merupakan tahap yang dilakukan setelah melakukan analisis kurikulum, analisis karakteristik siswa, analisis materi dan merumuskan tujuan. Dalam hal ini penulis menyusun LKS berbasis RME yang disusun sesuai dengan kebutuhan siswa. Berikut ini adalah bagian-bagian dari LKS.

\section{Development}

\section{a. Tahap Validasi LKS}

LKS yang telah selesai dirancang kemudian divalidasi oleh validator ahli desain dan ahli materi dengan menggunakan lembar validasi berupa angket dan melalui diskusi. Validasi ini bertujuan untuk menegetahui kevalidan LKS yang dibuat sudah layak atau tidak untuk digunakan atau diuji coba terhadap siswa. Uji validasi oleh ahli desain untuk mengetahui kevalidan LKS yang dinilai dari aspek format penulisan, bahasa yang digunakan, kemasan atau tampilan LKS dan penempatan gambar. Lembar angket validasi oleh materi bertujuan untuk mengetahui kevalidan LKS yang dinilai dari aspek isi, materi, tujuan dan pendekatan RME.

1) Validasi dari Ahli Desain 
Hasil penilaian setiap komponen oleh ahli desain terhadap pengembangan LKS berbasis RME melalui instrumen angket, Berikut adalah hasil validasi LKS oleh ahli desain.

Tabel 2. Hasil Validasi Ahli Desain Terhadap LKS Berbasis RME

\begin{tabular}{|c|l|c|c|}
\hline No & Aspek & Nilai Validasi & Kriteria \\
\hline 1. & Format Penulisan & $80 \%$ & Valid \\
\hline 2. & Bahasa & $100 \%$ & Sangat Valid \\
\hline 3. & Tampilan & $67 \%$ & Cukup Valid \\
\hline 4. & Penempatan gambar & $60 \%$ & Cukup Valid \\
\hline \multicolumn{2}{|l|}{ Validitas Keseluruhan } & $\mathbf{7 4 , 6 7 \%}$ & Valid \\
\hline
\end{tabular}

2) Validasi dari Ahli Materi

Hasil penilaian setiap komponen oleh ahli materi terhadap pengembangan LKS berbasis RME melalui instrument angket. Sedangkan distribusi skor angket Berikut adalah hasil validasi oleh ahli materi

Tabel 3. Hasil Validasi Ahli Materi Terhadap LKS Berbasis RME

\begin{tabular}{|r|l|c|l|}
\hline No & Aspek & Nilai Validasi & Kriteria \\
\hline 1. & Isi atau materi & $91,48 \%$ & Sangat Valid \\
\hline 2. & Aspek Tujuan & $76,67 \%$ & Valid \\
\hline 3. & Pendekatan RME & $76,67 \%$ & Valid \\
\hline \multicolumn{2}{|r|}{ Validasi Keseluruhan } & $\mathbf{8 1 , 7 5 \%}$ & Sangat Valid \\
\hline
\end{tabular}

3) Hasil Praktilitas Kelompok Terbatas

LKS berbasis RME yang telah praktis saat ujicoba kelompok kecil, selanjutnya dilakukan ujicoba kelompok besar kepada siswa dalam suatu kelas yang berjumlah 29 siswa, setelah menggunakan LKS siswa memberikan penilaian melalui angket uji praktilitas LKS. Berikut adalah hasil penilaian uji praktilitas pada saat ujicoba kelompok kecil

Tabel 4. Persentase Praktilitas Pada Saat Uji Coba Kelompok Terbatas

\begin{tabular}{|l|l|c|c|}
\hline No & \multicolumn{1}{|c|}{ Aspek } & Nilai Praktikalitas & Kriteria \\
\hline 1. & $\begin{array}{l}\text { Pemahaman siswa } \\
\text { terhadap materi }\end{array}$ & $91,86 \%$ & Sangat Praktis \\
\hline 2. & $\begin{array}{l}\text { Minat siswa terhadap } \\
\text { LKS }\end{array}$ & $95,97 \%$ & Sangat Praktis \\
\hline 3. & Penggunaan LKS & $92,75 \%$ & Sangat Praktis \\
\hline \multicolumn{2}{|l|}{ Praktikalitas Keseluruhan } & $\mathbf{9 4 , 1 6 \%}$ & Sangat Praktis \\
\hline
\end{tabular}


4) Data Hasil Posttest

Setelah siswa mengikuti pembelajaran dengan menggunakan LKS berbasis RME, selanjutnya siswa diberi soal posttest berupa tes kemampuan representasi matematis. Nilai posttest siswa dapat dilihat pada lampiran 11A, berikut hasil tes kemampuan representasi matematis siswa setelah menggunakan LKS berbasis RME.

Tabel 5. Hasil Tes Kemampuan Representasi Matematis Siswa

\begin{tabular}{|l|c|c|l|}
\hline No & Interval & Jumlah Siswa & Kriteria \\
\hline 1. & $75-100$ & 24 & Tuntas \\
\hline 2. & $0-74$ & 5 & Tidak Tuntas \\
\hline \multicolumn{2}{|c|}{ Rata-rata } & $\mathbf{9 0 , 7}$ & Tuntas \\
\hline
\end{tabular}

Berdasarkan tabel hasil tes kemampuan representasi matematis siswa tersebut 24 dari 25 siswa telah tuntas dalam pembelajaran dengan nilai diatas KKM, yaitu 75 dengan nilai rata-rata 90,7.

\section{PENUTUP}

\section{Simpulan}

Berdasarkan penelitian pengembangan LKS berbasis Realistic Mathematics Education (RME)yang telah dilakukan dapat disimpulkan:

a. Hasil pengembangan LKS berbasis pendekatan RME untuk memfasilitasi kemampuan representasi matematis siswa kelas VIII.1 SMP Negeri 2 Pasir Penyu dinyatakan valid dengan persentase kevalidan 78,21\%.

b. Hasil Pengembangan LKS berbasis pendekatan RME untuk memfasilitasi kemampuan representasi matematis siswa kelas VIII.1 SMP Negeri 2 Pasir Penyu dinyatakan sangat praktis dengan persentase kepraktisan $94,16 \%$.

c. LKS berbasis pendekatan RME dapat memfasilitasi kemampuan representasi matematis siswa kelas VIII.1 SMP Negeri 2 Pasir Penyu dengan persentase tingkat penguasaan $82,5 \%$.

\section{Rekomendasi} berikut:

Beberapa rekomendasi yang peneliti berikan berdasarkan penelitian ini sebagai

a. Kepada pembaca atau peneliti lain yang akan melakukan penelitian pengembangan menggunakan LKS berbasis Realistic Mathematics Education, direkomendasikan untuk memilih materi pembelajaran yang yang real dan memiliki banyak soal-soal terbuka.

b. Kepada pembaca atau peneliti lain yang akan melakukan penelitian pengembangan menggunakan LKS, untuk mengembangkan dengan materi yang berbeda.

c. Pengembangan LKS matematika berbasis Realistic Mathematics Education ini belum sampai pada tahap eksperimen untuk menguji efektifitas LKS bagi peneliti lain agar dapat melakukan penelitian sampai pada tahap efektifitas agar lebih sempurna lagi.

\section{DAFTAR PUSTAKA}

Abu Bakar, Muhammad. 1981. Pedoman Pendidikan dan Pengajaran. Surabaya:Usaha Nasional. 
Agus N. Cahyo. 2013. Panduan Aplikasi Teori-Teori Belajar Mengajar Teraktual dan Terpopuler. Jogjakarta: DIVA Press.

Arikunto, Suharsimi \& Cepi Safrudin. 2009. Evaluasi Program Pendidikan. Jakarta: Bumi Aksara.

Arikunto, Suharsimi. 2010. Manajemen Penelitian. Jakarta: Rineka.

Anas Sudijiono. 2008. Pengantar Evaluasi Pendidikan. Jakarta: PT RajaGrafindo.

Aunurrahman, 2011. Belajar dan Pembelajaran. Bandung: Alfabeta.

Amir, Zubaidah \& Risnawati, 2015. Psikologi Pembelajaran Matematika. Yogyakarta:Aswaja Pressindo.

Burhan Iskandar Alam. Peningkatan Kemampuan Pemahaman dan Komunikasi matematika siswa SD melalui pendekatan RME prosiding seminarNasional. FMIPA UNY 10 November 2012.

David, Eggen \& Kauchak. 2000.Method for Teaching Metode-Metode pengajaran meningkatkan belajar siswa TK - SMA. Yogyakarta: Pustaka Pelajar.

Didi Suhaedi. Peningkatan Kemampuan Komunikasi Matematis Prosiding Seminar Nasional Matematika. FMIPA UNY 10 Desember 2012.

Eko Putro, Widyoko. 2014. Evaluasi Program Pembelajaran. Yogyakarta: Pustaka Belajar.

Hartono. 2011. Metodologi Penelitian. Pekanbaru: Zanafa Publishing.

Hamdani. 2011. Strategi Belajar Mengajar. Bandung: Pustaka Setia.

Kartini. Peranan Representasi dalam Pembelajaran Matematika. Prosiding.Seminar Nasional FMIPA UNY Yogyakarta 5 Desember 2009.

Latief Awaludin. 2012.AL-Qura'an Ummul Mukmin. Jakarta: WALI.

Mulyatiningsih, Endang. 2014. Metode Penelitian Terapan Bidang Pendidikan.Bandung: Alfabeta.

Oemar, Hamalik. 2010. Perencanaan Pengajaran Berdasarkan Pendekatan Sistem. Jakarta:Bumi Aksara.

Prastowo, Andi. 2013. Panduan Kreatif Membuat Bahan Ajar Inovatif. Yogyakarta:Diva pres`

Punaji, Setyosary. 2013. Metode Penelitian Pendidikan \& Pengembangan, Jakarta:Kencana.

Ranjabar, Jacobus. 2015. Dasar-dasar Logika Sebuah Langkah Awal Untuk Masuk ke Berbagai Disiplin Ilmu dan Pengetahuan. Bandung: Alfabeta.

Risnawati. 2008.Strategi Pembelajaran Matematika. Pekanbaru: Suska Pers.

Riduwan. 2011.Skala Pengukuran Variabel-Variabel Penelitian, Bandung: Alfabeta.

Rohman, Muhammad, dkk. 2013.Strategi \& Desain Pengembangan Sistem

Pembelajaran. Jakarta: Prestasi Pustaka.

Rochmad. Model Pengembangan Perangkat Pembelajaran Matematika. Jurnal. FMIPA UNNES, 1 juni 2012.

Sabirin, Muhammad. Representasi dalam Pembelajaran Matematika. Jurnal IAINAntasaari, Januari 2014.

Saleh, Muhammad. Pembelajaran Kooperatif dengan Pendekatan PMR. Jurnal FKIP Universitas Serambi Mekah Banda Aceh, September 2012. 